\title{
Yield Grade and Quality Assessment of Native Buffalo Meat and Beef at Different Ages
}

\author{
B. K. Roy, N. Huda*, K. S. Huque, N. Sultana, \& N. R. Sarker \\ Animal Production Research Division, Bangladesh Livestock Research Institute \\ Savar, Dhaka-1341, Bangladesh \\ *Corresponding author: hudanazmul1971@gmail.com \\ (Received 06-05-2020; Revised 02-07-2020; Accepted 15-07-2020)
}

\begin{abstract}
Boosting meat production potential possibly happens when people will judge meat quality and use their livestock wisely, as they meet up their demand from promising animal like buffalo. To evaluate the productive performances and quality assessments of beef and buffalo meats, cattle (Pabna) and buffalo (Native, swamp type) were fattened for 120 days with a single plane of nutrition in a $2 \times 3$ (Species $\times$ Age) factorial experiment. By slaughtering, the carcass and non-carcass characteristics, primal cuts, $\mathrm{pH}$, drip loss, cooking loss, color, intramuscular fat of meat, marbling score, and yield grade of meat were determined through univariate GLM procedure based CRD analysis. Live and carcass weights of buffalo were significantly higher $(p<0.001)$, but the dressing percentage was significantly lower $(p<0.001)$ than cattle $(52.1 \%$ \& $55.3 \%$, respectively). Species variation and age have a great impact on the yield of primal cuts. Meat: bone of cattle (5.33:1.00) was significantly better $(p<0.001)$ than buffalo (4.57:1.00). Buffalo meat was darker and reddish $(p<0.01)$ in color, and with the increment of age, it was increased $(p<0.001)$. A little amount $(p<0.001)$ of intramuscular fat was found in buffalo meat $(0.44 \%)$ than cattle $(3.31 \%)$. The marbling score was measured higher $(\mathrm{p}<0.001)$ in cattle than buffalo $(5.00$ and 3.85 , respectively). Buffalo meat scored 3 in 5 scale yield grade point where beef gained 3.5 scores and showed a significant $(p<0.05)$ difference. Finally, buffalo meat scored better than beef with the measures of yield grade, marbling score, and fat percentage, though its lower carcass yield and demerits of a reddish color.
\end{abstract}

Keywords: buffalo meat; beef; carcass; meat quality; yield grade

\section{INTRODUCTION}

Cattle and buffalo are the most valuable resource of Bangladesh to reconcile the meat demands. Cattle and buffalo will meet almost half of the total meat demand of the local market directly (Rahman, 2012). In Bangladesh, every year, from the populations of 23.20 million cattle and 1.46 million buffaloes, 0.4 and 0.1 million metric tons of meat, respectively are produced (Fatema, 2014). Buffalo is a neglected species and it is used widely only for draught purposes. They are slaughtered usually at old age when their meat becomes tender and sold it in the disguise of cattle meat in the market. In Brazil, buffalo is still also considered as an exotic species and almost $90 \%$ of its meat marketed as cattle meat (Mello et al., 2017). However, in young buffalo, meat fat, collagen, muscle fiber diameter, and share force values are lower compared to spent animals (Kandeepan et al., 2009b). It is important to know the best time of animals slaughtering for marketing and which measures should be prioritized for producing quality meats from buffalo or cattle.

Actually, people are uninformed about the production potential of buffalo. That condition probably the reason why buffalo deems as a neglected species and in some regions of Bangladesh, buffaloes are reared depending on the available feed resources (Huque \& Borghese, 2013). However, this species is committed to producing maximum with trivial feed and management. This species can utilize a straw, residues of crop, or even coarse feed and can convert it to high quality meat (Kandeepan et al., 2009a). Not only that, buffalo meat is also considered as safe meat for humans among red meats because of its high protein concentration, low fat-cholesterol-calories, and the presence of more $\beta$-carotene and minerals than superior beef grade meat (Naveena et al., 2011).

With the increased purchasing ability, awareness also increases among the people and they are seeking quality meat nowadays. Their concerns are to avoid fat-rich products like red meats which are associated with different types of health maladies. In comparison to red meat like beef or pork, buffalo meat is superior regarding fat and cholesterol appearance and contents (Singh et al., 2018). Therefore, it is truly required to provide quality meat to the population by encouraging the production of lean meat from buffalo at the right time. Otherwise, an imputed resource will remain unutilized 
and upmost production will be hampered. If we just look at India, just for intentional negligence or for saving dams milk, they removed 10 million male buffalo every year, which incur a loss of about US \$ 18 million and as a result, raising of male buffalo become nonremunerative in the production chain (Ranjhan, 2014). However, the purchaser's perception on buffalo meat has a negative concern in the aspect of quality meat. Therefore, switching the positive perceptions of people on buffalo meat through explicating the comparative carcass characteristics of young cattle and buffalo should be the main attempt.

Indeed, cattle and buffalo meats can be compared in parallel in the context of quality, if it is slaughtered at the same age or weight (Irurueta et al., 2008). Actually, yield grade is an important characteristic that has an impact on consumer's purchasing, which directly correlates with consumer and price (Cheng et al., 2015). Therefore, it is really required to know and evaluate the carcass characteristics of local cattle and buffalo. However, an established buffalo fattening technology using youth animals for getting the popularity of buffalo meat will be a great approach. Besides this, following the same fattening technology, it is required to evaluate carcass characteristics. This approach may help to increase the production potential of meat which will associate to meet up the market demand swiftly and at last, it may exploit the exporting opportunity further. For creating all these opportunities, the comparison of buffalo meat and beef is truly required first, which has never been addressed in this region. Therefore, the present study was conducted to determine the comparative performances of buffalo and cattle on meat production, productivity, and quality assessment.

\section{MATERIALS AND METHODS}

\section{Place, Experimental Design, Animals, and Diets}

A $2 \times 3$ factorial experiment of completely randomized design (CRD) was carried out at Bangladesh Livestock Research Institute (BLRI), Savar, Dhaka and quality related tests were done at Animal Nutrition and Meat Laboratory of BLRI. Species of animal (native Buffalo \& Cattle) was considered as factor A and stages of the age of the animal $(28,34$, and 40 months) were considered as factor B. There is no recognized breed in Bangladesh (Hamid et al., 2016), native buffalo, who has some sort of swamp type characters, was used for this experiment. Eighteen native buffalo (swamp type, used for meat purpose) and 18 cattle bulls (pabna cattle, mainly used for meat purpose) of three different ages were taken and divided them in six $(2$ species $\times 3$ ages) treatments where each treatment consisted of six animals.

A fattening program of 120 days (including 15 days for adjustment) was conducted in a single plane of nutrition where roughage to concentrate feeding ratio was 50:50. After adjustment, the initial live weights of animals were measured and subsequent weights were measured at an interval of 10 days by a platform digital electronic scale (weighing range $0.00 \mathrm{~kg}$ to $1,000 \mathrm{~kg}$ and minimum graduation $\pm 0.1 \mathrm{~kg}$ ).

During the trial period, feeding of maize (Zea mays; BARI hybrid) silage was provided ad libitum, but the desired roughage to concentrate ratio (50:50) was adjusted periodically in ten days interval by changing the daily per head allowances and provided to the animal accordingly. Maize silage was prepared previously.

Prior to the trial, cultivated maize grass was harvested at $90^{\text {th }}$ days of sowing when it was at dough stage, chopped it into $6-8 \mathrm{~cm}$ and ensiled for 30 days. The dry matter and crude protein percentage of maize silage were found $22.63 \%$ and $8.09 \%$, respectively. The concentrate mixture comprised of crushed wheat (20\%), wheat bran $(40 \%)$, khesari bran $(20 \%)$, soybean meal $(15 \%)$, common salt $(1 \%)$, di-calcium phosphate $(3 \%)$, limestone $(1 \%)$, and vitamin-mineral premix $(0.01 \%)$ which costs $0.35 \$ / \mathrm{kg}$; mixed manually and fortnightly. The dry matter and crude protein percentages of mixed concentrate were $88.83 \%$ and $18.30 \%$, respectively. Animals were tied individually, and half of their ration was offered in the morning and the remaining half was given in the afternoon. Each bull was weighed before morning feeding. Endex® (Levamesol BP 600 $\mathrm{mg}$ ) at a dose of $20 \mathrm{mg} / \mathrm{kg}$ live weight, was applied for dewormed all experimental animals. Fresh water was available during all the trial period.

\section{Slaughter and Carcass Evaluation}

From each group, five bulls out of six bulls were randomly selected for slaughtering when their ages were 28, 34, and 40 months as factor B considered. Bulls have fasted for 24 hours and then the individual live weight was recorded just before slaughter. All the bulls were slaughtered at abattoir of BLRI following the Halal method as bled by cutting throat and then slaughtered by severing the head at its articulation on the occipitoatlantal space. The hide of the animal was removed in a domestic manner with a sharp knife. Blood was collected in a pre-weighed bucket and weighed again. Just after slaughtering, the head was separated at the atlanto-oxipital joint. Carpals and tarsals were also separated apart with. Head, hide, spleen, heart with and without fat, kidney and kidney knob, pelvic fat, visceral fat, lung with trachea, liver, gall bladder, bile, testes, and penis were removed and weighed using a digital scale. The entire digestive tract and rumen filled with content were weighed and then depleted completely and weighed again and recorded. Halving and quartering of carcasses and cutting of different primal cuts following vertebral formula (Cervical 7 Thoracic ${ }_{13}$ Lumbar $_{6}$ Sacral $_{5}$ Caudal $_{13-21}$ ).

After removing offal parts, warm carcasses of each animal was weighed. Carcasses were chilled at $4^{\circ} \mathrm{C}$ for $24 \mathrm{~h}$ and then again weighed to determine the dressing percentage (DP). DP was calculated from both the proportion of warm carcass weight (WCW) and chilled carcass weight (CCW) of the live weight. The chilled carcasses were divided into different wholesale cuts as per the Australian Carcass Portioning Scheme. For measuring Longissimus Muscle Area (LMA) the hot carcass was split between $12^{\text {th }}$ and $13^{\text {th }}$ ribs. From the cross section 
the $L M A$ was traced five times onto an acetate sheet. The marked acetate sheet area was cut down and weighed in an electric balance and its area in $\mathrm{cm}^{2}(X)$ was calculated following the formula:

$$
X=a / b \times c
$$

where c was the weight of marked acetate sheet, b was the weight, and a was the area (in $\mathrm{cm}^{2}$ ) of the same another acetate sheet. The guideline of Korea Institute of Animal Products Quality Evaluation (KAPE) was followed (Lee \& Choi, 2019) and the procedure was repeated three times, and the average of the three measurements was considered as the calculated area of an eye muscle.

\section{Yield Grade}

Marbling score (1-9) of meat in eye muscle $\left(12^{\text {th }}\right.$ and $\left.13^{\text {th }} \mathrm{rib}\right)$ was done visually, according to Burson (2005). Color brightness of meat (eye muscle; $12^{\text {th }}$ and $13^{\text {th }}$ rib) was evaluated by visual appraisal following the color score (3-5), where $5=$ very good, which looks light cherry-red; $4.5=$ good, which looks light cherry-red to slightly dark red; $4=$ average, which looks moderately light red to moderately dark red; $3.5=$ below average, which looks moderately dark red to dark red and $3=$ inferior, which looks dark red to very dark red (Mir et al., 2002). Fat thickness was taken by a caliper averaging three points between the $12^{\text {th }}$ and $13^{\text {th }}$ ribs and over the longissimus muscle. For the calculation of Yield Grade (YG), the guideline of United States Department of Agriculture (USDA) was followed (Hale et al., 2013). To determine meat to bone ratio, muscle was separated from bone using a sharp knife.

\section{Muscle Sampling and Chemical Analysis}

Meat samples (20 g) for the analysis of proximate composition of meat were taken from longissimus dorsi muscle of each slaughtered bull and packed separately after labeling. A digital pH meter (Model no. HANNA Instruments, HI 2211 pH/Orpmeter) was used for measuring $\mathrm{pH}$ of warm and chilled meat. Colors of meat were identified by using Chromameter (CR400, Konica Minolta inc. Japan). Dry matter (DM), organic matter $(\mathrm{OM})$, and crude protein $(\mathrm{CP})$ were determined following AOAC (2005). Neutral detergent fiber (NDF) and acid detergent fiber (ADF) were determined following the procedure of Van Soest et al. (1991). Drip loss and Cook loss of meat was measured following the procedure described by Yang et al. (2006).

\section{Statistical Analysis}

The data collected were subjected to analysis of variance (Steel \& Torrie, 1980) using univariate GLM procedure based on Completely Randomized Design (CRD). The age of the animal and species were included as the main effect. A least squares regression approach in SPSS, 17 computer software packages were used to describe statistical relations between the treatment responses of a $2 \times 3$ factorial experiment with two species and three age groups as the main factors. Least Significant Difference (LSD) test at 5\% level of probability was applied as a post hoc test to compare the differences among treatment means. The statistical model applied for all parameters was:

$$
\mathrm{y}_{\mathrm{ijk}}=\mu+\mathrm{y}_{\mathrm{k}}+\alpha_{\mathrm{i}}+\beta_{\mathrm{j}}+\left(\alpha_{\mathrm{i}} \times \beta_{\mathrm{j}}\right)+\mathrm{e}_{\mathrm{ijk}}
$$

where $y_{\mathrm{ijk}}$ was the dependent variable, $\mu$ was overall mean, $y_{k}$ was the random effect of $k^{\text {th }}$ treatment $(k=1$, $\ldots . ., 6), \mathrm{e}_{\mathrm{ijk}}$ was the random error, $\alpha_{\mathrm{i}}(\mathrm{i}=1,2$; two species i.e., cattle and buffalo bull), $\beta_{j}(j=1,2,3$; three age groups i.e., 28, 34, and 40 months), and $\alpha_{\mathrm{i}} \times \beta_{\mathrm{j}}$ were the fixed effects of $i^{\text {th }}$ animal species (cattle, buffalo) $j^{\text {th }}$ age group (28, 34, and 40 months) and their interactions, respectively.

\section{RESULTS}

\section{Carcass Yield and Characteristics}

Carcass yield and characteristics of local cattle and buffalo bulls slaughtered at different ages are presented in Table 1. At slaughtering, in the interaction of species and age of animals, 5\% level of significance was observed. Then, significantly higher $(\mathrm{p}<0.001)$ live weight was found in buffalo bulls (464 kg) than in cattle (389 $\mathrm{kg}$ ) and it was also observed that, with the increasing age of bulls, live weights of both the species were significantly $(p<0.001)$ increased. In the case of body condition score, no significant interaction of age with the species was found. Body condition score of buffalo was significantly higher $(p<0.01)$ than that of cattle and with the increasing age of both types of bulls, body condition scores were also significantly different $(p<0.01)$.

Age and interaction of "age \& species" had no significant effect on dressing percentage, whereas species itself had a notable significant effect $(p<0.001)$ on dressing percentage. Carcass weights (warm and chilled) of buffalo bulls were significantly higher $(p<0.01)$ than that of cattle. Carcass weights (warm and chilled) of high aged bulls were higher significantly $(p<0.001)$ than lower aged bulls of both species. Even though carcass weights were significantly high in buffalo (warm and chilled weights of $242 \mathrm{~kg}$ and $240 \mathrm{~kg}$, respectively) than in cattle (warm and chilled carcass: $215 \mathrm{~kg}$ and $212 \mathrm{~kg}$, respectively), the dressing percentage was found significantly low in buffalo (warm and chilled carcass: 52,1\% and $51.6 \%$, respectively) than in cattle (warm and chilled carcass: $55.3 \%$ and $54.7 \%$, respectively).

Meat to the bone proportion of the carcass of cattle (5.33:1.00) was found significantly better $(p<0.001)$ than that of buffalo $(4.57: 1.00 \mathrm{~kg})$ where there were no significant effects of age or "age and species" interaction was found. Measurements of longissimus muscle (Eye muscle) area between the species and the interaction value of "age and species" did not show any significant difference. However, there was a significant increase $(\mathrm{p}<0.05)$ in longissimus muscle area $\left(\mathrm{cm}^{2}\right)$ was observed in "28 months" to "40 months" aged animal, as was shown in Table 1. 


\section{Yield of Primal Cut}

The primal cuts of all the carcass were expressed in percent of chilled carcass weight. There were no significant effects of age and interaction of "age and species" on the yields of forequarter and hindquarter (Table 2). There were only species of animals that had significant effects on the yields of forequarter and hindquarter. The forequarter of cattle $(52.95 \%)$ was significantly heavier $(\mathrm{p}<0.001)$ than that of buffalo $(51.00 \%)$ were at the same time, the hindquarter of cattle was found significantly $(\mathrm{p}<0.001)$ lighter $(47.05 \%)$ than that of buffalo $(49.00 \%)$. No age or "age and species" interaction effects were observed in any species in this case. Most of the primal cuts showed the species effects on yield and some of the cuts showed the age effects, but "species and age" in- teraction effect was not observed in any cuts except the neck. Species $(\mathrm{p}<0.01)$, age $(\mathrm{p}<0.05)$, and "age and species" interaction had significant $(p<0.01)$ effects on neck yield where the better yield was observed in cattle than in buffalo, and the neck yield was significantly increased with the increase of age.

No age or "age and species" interaction effects were observed in any species in case of silverside, knuckle, and sirloin. However, age showed significant effect on chuck yield at 5\% level of significance. Chuck percentage was significantly higher $(\mathrm{p}<0.001)$ in the forequarter of cattle $(8.41 \%)$ than that of buffalo $(6.84 \%)$. However, in hindquarter, silverside, knuckle, and sirloin were significantly higher $(\mathrm{p}<0.001)$ in buffalo $(4.63 \%, 3.83 \%$, and $5.34 \%$, respectively) than in cattle $(3.90 \%, 3.31 \%$, and $4.75 \%$, respectively).

Table 1. Carcass yield characteristics of cattle and buffalo

\begin{tabular}{|c|c|c|c|c|c|c|c|c|c|}
\hline \multirow{2}{*}{ Variables } & \multicolumn{2}{|c|}{ Species } & \multicolumn{3}{|c|}{ Age (months) } & \multirow{2}{*}{ SED } & \multicolumn{3}{|c|}{ Sig. level } \\
\hline & Cattle & Buffalo & 28 & 34 & 40 & & $S$ & $\mathrm{~A}$ & $\mathrm{~S} \times \mathrm{A}$ \\
\hline LW at slaughter, $\mathrm{kg}$ & 389 & 464 & $383^{c}$ & $426^{b}$ & $471^{a}$ & 8.54 & $* * *$ & $* * *$ & * \\
\hline BCS (6-point scale) & 5.13 & 5.36 & $5.08^{\mathrm{b}}$ & $5.25^{\mathrm{a}}$ & $5.41^{\mathrm{a}}$ & 0.05 & $* *$ & $* *$ & NS \\
\hline Warm carcass wt, $\mathrm{kg}$ & 215 & 242 & $202^{c}$ & $228^{b}$ & $256^{\mathrm{a}}$ & 5.49 & $* *$ & $* * *$ & NS \\
\hline Warm dressing, \% & 55.3 & 52.1 & 53.1 & 53.5 & 54.4 & 0.42 & $* * *$ & NS & NS \\
\hline Chilled carcass wt., $\mathrm{kg}$ & 212.87 & 240.0 & $200.02^{c}$ & $226.20^{\mathrm{b}}$ & $253.10^{\mathrm{a}}$ & 5.51 & $* *$ & $* * *$ & NS \\
\hline Chilled dressing, \% & 54.74 & 51.64 & 52.57 & 53.11 & 53.89 & 0.42 & $* * *$ & NS & NS \\
\hline Forequarter, \% chilled & 52.95 & 51.00 & 51.42 & 52.08 & 52.43 & 0.33 & $* * *$ & NS & NS \\
\hline Hindquarter, \% chilled & 47.05 & 49.00 & 48.58 & 47.92 & 47.57 & 0.33 & $* * *$ & NS & NS \\
\hline Meat \& bone ratio & 5.33 & 4.57 & 4.77 & 5.07 & 5.02 & 0.12 & $* * *$ & NS & NS \\
\hline Longs. muscle area, $\mathrm{cm}^{2}$ & 82.6 & 81.5 & $77.7^{\mathrm{b}}$ & $79.6^{\mathrm{bc}}$ & $88.9^{\mathrm{ac}}$ & 2.84 & NS & $*$ & NS \\
\hline
\end{tabular}

Note: $\mathrm{S}=$ species; $\mathrm{A}=$ age; $\mathrm{S} \times \mathrm{A}=$ Species $\times$ age interactions; ${ }^{*}=\mathrm{p}<0.05 ;{ }^{* *}=\mathrm{p}<0.01 ;{ }^{* * *}=\mathrm{p}<0.001$; NS= Non-significant; $\mathrm{SED}=$ standard error of difference.

Table 2. Yield of primal cut (\%, chilled carcass weight) of cattle and buffalo

\begin{tabular}{|c|c|c|c|c|c|c|c|c|c|}
\hline \multirow{2}{*}{ Variables } & \multicolumn{2}{|c|}{ Species } & \multicolumn{3}{|c|}{ Age (months) } & \multirow{2}{*}{ SED } & \multicolumn{3}{|c|}{ Sig. level } \\
\hline & Cattle & Buffalo & 28 & 34 & 40 & & $S$ & A & SxA \\
\hline Forequarter & 52.95 & 51.00 & 51.42 & 52.08 & 52.43 & 0.33 & $* * *$ & NS & NS \\
\hline Rib & 2.75 & 2.89 & 2.88 & 2.79 & 2.79 & 0.14 & NS & NS & NS \\
\hline Short plate & 8.67 & 7.59 & $7.27^{\mathrm{b}}$ & $8.01^{\mathrm{bc}}$ & $9.09^{\mathrm{ac}}$ & 0.39 & * & * & NS \\
\hline Brisket & 9.87 & 9.68 & 10.10 & 9.48 & 9.75 & 0.22 & NS & NS & NS \\
\hline Chuck & 8.41 & 6.84 & $7.85^{a}$ & $8.17^{a}$ & $6.85^{\mathrm{b}}$ & 0.26 & $* * *$ & * & NS \\
\hline Fore shank & 2.72 & 2.72 & 2.88 & 2.62 & 2.66 & 0.09 & NS & NS & NS \\
\hline Neck & 9.37 & 8.44 & $8.40^{\mathrm{b}}$ & $8.83^{\mathrm{bc}}$ & $9.47^{\mathrm{ac}}$ & 0.21 & $* *$ & * & $* *$ \\
\hline Hind quarter & 47.05 & 49.00 & 48.58 & 47.92 & 47.57 & 0.33 & $* * *$ & NS & NS \\
\hline Topside & 5.85 & 5.55 & $6.07^{\mathrm{a}}$ & $5.39^{\mathrm{b}}$ & $5.65^{\mathrm{b}}$ & 0.10 & $*$ & $* * *$ & NS \\
\hline Silverside & 3.90 & 4.63 & 4.33 & 4.21 & 4.26 & 0.08 & $* * *$ & NS & NS \\
\hline Knuckle & 3.31 & 3.83 & 3.69 & 3.49 & 3.53 & 0.06 & $* * *$ & NS & NS \\
\hline Loin & 0.39 & 0.38 & 0.40 & 0.36 & 0.41 & 0.02 & NS & NS & NS \\
\hline Tender loin & 1.19 & 1.24 & 1.25 & 1.19 & 1.20 & 0.03 & NS & NS & NS \\
\hline Sirloin & 4.75 & 5.34 & 4.89 & 5.11 & 5.13 & 0.11 & $* * *$ & NS & NS \\
\hline Strip loin & 4.66 & 4.24 & $4.17^{\mathrm{b}}$ & $4.65^{\mathrm{ac}}$ & $4.53^{\mathrm{bc}}$ & 0.13 & * & * & NS \\
\hline Hind shank & 3.31 & 3.54 & $3.63^{\mathrm{a}}$ & $3.31^{\mathrm{b}}$ & $3.33^{\mathrm{b}}$ & 0.08 & * & * & NS \\
\hline Flank & 2.93 & 2.24 & $3.00^{\mathrm{a}}$ & $2.64^{\mathrm{a}}$ & $2.12^{\mathrm{b}}$ & 0.14 & $* *$ & $* *$ & NS \\
\hline Heel muscle & 2.93 & 2.24 & $3.00^{\mathrm{a}}$ & $2.64^{\mathrm{a}}$ & $2.12^{\mathrm{b}}$ & 0.14 & $* *$ & $* *$ & NS \\
\hline Hind sheen & 1.33 & 1.62 & $1.57^{\mathrm{a}}$ & $1.39^{\mathrm{bc}}$ & $1.47^{\mathrm{ac}}$ & 0.03 & $* * *$ & $* *$ & NS \\
\hline Eye of silver side & 1.63 & 1.60 & $1.69^{a}$ & $1.56^{\mathrm{bc}}$ & $1.60^{\mathrm{ac}}$ & 0.03 & NS & * & NS \\
\hline
\end{tabular}

Note: $\mathrm{S}=$ species; $\mathrm{A}=$ age; $\mathrm{S} \times \mathrm{A}=$ Species $\times$ age interactions; ${ }^{*}=\mathrm{p}<0.05 ;{ }^{* *}=\mathrm{p}<0.01 ;{ }^{* * *}=\mathrm{p}<0.001 ; \mathrm{NS}=$ Non-significant; $\mathrm{SED}=$ standard error of difference. 
In hindquarter, the hind sheen percentage was significantly higher $(p<0.001)$ in buffalo $(1.62 \%)$ than in cattle $(1.33 \%)$ and a significant age effect $(p<0.01)$ of this cut was found where yield was lower when age was higher. Yields of flank and heel muscle significantly differed between the species $(p<0.01)$ and among the age $(p<0.01)$ but no significant interaction effect of age and species on the yields. Proportions of flank and heel muscle were higher in cattle than in buffalo, and it was shown that the portion of these two cuts was higher in the younger age than in the older age. In case of the topside of hindquarter, the same trend was observed where yield was higher in the younger age $(p<0.01)$ compared to the older age. Short plate, strip loin, and hind shank showed significant differences in yield proportion between the species $(p<0.05)$ and among the ages $(p<0.05)$. Finally, it is observed that species variation has a great impact on yield of primal cuts, and the age of animal somehow influences the yields of primal cuts.

\section{Yield and Characteristics of Non-carcass Components}

No interaction effect between species and age was observed in any non-carcass body parts, except in shank weight (Table 3). The absolute and relative weights of skin $(56.60 \mathrm{~kg}$ or $12.21 \% \mathrm{LW})$, spleen $(1.62 \mathrm{~kg}$ or $0.35 \%$ LW), and shank (10.09 kg or $2.17 \% \mathrm{LW})$ of buffalo were found heavier $(p<0.001)$ than those of cattle which showed the significant species effect. The age of both species also showed minimal effects on the yields where yields were higher in the older animal except in proportion with body weights in case of skin and shank.

In case of spleen, the effect of age difference was significantly observed when it was measured as body proportion or percentage. There was head $(\mathrm{p}<0.001)$, blood $(p<0.01)$, liver $(p<0.01)$, and lung \& trachea $(p<0.001)$ of buffalo were found significantly heavier than those of cattle, but with the proportion of bodyweight the yield did not show any significant difference. Among these four parts, blood and liver showed significant $(\mathrm{p}<0.05)$ effects of the age.

The gallbladder $(90 \mathrm{~g})$ and penis $(457 \mathrm{~g})$ of cattle were significantly bigger $(p<0.01)$ than those of buffalo (47 $\mathrm{g}$ and $359 \mathrm{~g}$, respectively) and the penis weight was increased significantly $(\mathrm{p}<0.05)$ with the increase of age. Testis and tail yield also found significantly higher $(p<0.05)$ in cattle than in buffalo. Again, the tail weight in proportion to body weight differed signifi-

Table 3. Yield of non-carcass edible and in-edible components

\begin{tabular}{|c|c|c|c|c|c|c|c|c|c|c|}
\hline \multirow{2}{*}{ Variables } & \multirow{2}{*}{ Unit } & \multicolumn{2}{|c|}{ Species } & \multicolumn{3}{|c|}{ Age (months) } & \multirow{2}{*}{ SED } & \multicolumn{3}{|c|}{ Sig. level } \\
\hline & & Cattle & Buffalo & 28 & 34 & 40 & & $S$ & $\mathrm{~A}$ & SxA \\
\hline \multirow[t]{2}{*}{ Skin } & $\mathrm{kg}$ & 33.88 & 56.60 & $40.00^{a}$ & $45.36^{\mathrm{ac}}$ & $50.36^{\text {bc }}$ & 1.87 & $* * *$ & * & NS \\
\hline & $\% L W$ & 8.72 & 12.21 & 10.21 & 10.63 & 10.54 & 0.41 & $* * *$ & NS & NS \\
\hline \multirow[t]{2}{*}{ Head } & $\mathrm{kg}$ & 20.14 & 26.54 & 22.15 & 22.53 & 25.36 & 1.02 & $* * *$ & NS & NS \\
\hline & $\% L W$ & 5.25 & 5.71 & 5.80 & 5.29 & 5.34 & 0.25 & NS & NS & NS \\
\hline \multirow[t]{2}{*}{ Blood } & $\mathrm{kg}$ & 15.37 & 21.34 & 19.17 & 17.52 & 18.38 & 1.19 & $* *$ & NS & NS \\
\hline & $\% L W$ & 3.99 & 4.63 & $4.91^{\mathrm{a}}$ & $4.12^{\mathrm{ac}}$ & $3.90^{\mathrm{bc}}$ & 0.26 & NS & * & NS \\
\hline \multirow[t]{2}{*}{ Liver } & $\mathrm{kg}$ & 3.95 & 4.70 & $4.13^{\mathrm{b}}$ & $4.34^{\mathrm{bc}}$ & $4.51^{\mathrm{ac}}$ & 0.09 & $* *$ & * & NS \\
\hline & $\%$ LW & 1.03 & 1.02 & $1.09^{a}$ & $1.02^{\mathrm{ac}}$ & $0.96^{\text {bc }}$ & 0.02 & NS & * & NS \\
\hline \multirow[t]{2}{*}{ Spleen } & $\mathrm{kg}$ & 1.12 & 1.62 & 1.38 & 1.32 & 1.41 & 0.06 & $* * *$ & NS & NS \\
\hline & $\%$ LW & 0.29 & 0.35 & $0.36^{\mathrm{a}}$ & $0.31^{\mathrm{b}}$ & $0.30^{\mathrm{b}}$ & 0.01 & $* *$ & $*$ & NS \\
\hline \multirow[t]{2}{*}{ Lung \& trachea } & $\mathrm{kg}$ & 2.74 & 3.55 & 3.01 & 3.13 & 3.29 & 0.13 & $* * *$ & NS & NS \\
\hline & $\%$ LW & 0.71 & 0.77 & 0.78 & 0.73 & 0.70 & 0.03 & NS & NS & NS \\
\hline Gallbladder & g & 90 & 47 & 56 & 66 & 83 & 8.0 & $* *$ & NS & NS \\
\hline Bile & $\mathrm{g}$ & 219 & 270 & 274 & 163 & 296 & 40.9 & NS & NS & NS \\
\hline Testis & g & 399 & 248 & 301 & 308 & 362 & 42.5 & * & NS & NS \\
\hline Penis & $\mathrm{g}$ & 457 & 359 & $358^{\mathrm{b}}$ & $422^{\mathrm{bc}}$ & $444^{\mathrm{ac}}$ & 21.2 & $* *$ & * & NS \\
\hline \multirow[t]{2}{*}{ Tail } & $\mathrm{kg}$ & 492 & 390 & 383 & 474 & 466 & 27.8 & $*$ & NS & NS \\
\hline & $\% L W$ & 0.31 & 0.16 & 0.22 & 0.24 & 0.25 & 0.01 & $* * *$ & NS & NS \\
\hline \multirow[t]{2}{*}{ Shank } & $\mathrm{kg}$ & 5.52 & 10.09 & $7.29 \mathrm{~b}$ & $7.45^{\mathrm{b}}$ & $8.68^{a}$ & 0.22 & $* * *$ & $* *$ & * \\
\hline & $\%$ LW & 1.43 & 2.17 & 1.85 & 1.75 & 1.80 & 0.04 & $* * *$ & NS & NS \\
\hline Heart & $\% L W$ & 0.30 & 0.40 & 0.35 & 0.35 & 0.35 & 0.008 & $* * *$ & NS & NS \\
\hline Kidney & $\%$ LW & 0.16 & 0.16 & 0.17 & 0.15 & 0.15 & 0.004 & NS & NS & NS \\
\hline \multicolumn{11}{|c|}{ Gastrointestinal (GI) tract } \\
\hline $\begin{array}{l}\text { Total GI tract } \\
\text { (with content) }\end{array}$ & $\mathrm{kg}$ & 53.32 & 61.26 & $52.63^{\mathrm{b}}$ & $58.21^{\mathrm{a}}$ & $61.03^{a}$ & 1.45 & $* * *$ & $* *$ & NS \\
\hline \multirow[t]{2}{*}{ Empty stomach } & $\mathrm{kg}$ & 9.67 & 11.97 & $9.93^{\mathrm{b}}$ & $11.00^{\mathrm{a}}$ & $11.52^{\mathrm{a}}$ & 0.27 & $* * *$ & $* *$ & NS \\
\hline & $\%$ LW & 2.50 & 2.59 & 2.59 & 2.58 & 2.46 & 0.05 & NS & NS & NS \\
\hline \multirow[t]{2}{*}{ Empty rumen } & $\mathrm{kg}$ & 4.84 & 6.30 & $5.11^{\mathrm{b}}$ & $5.70 \mathrm{a}$ & $5.90 \mathrm{a}$ & 0.17 & $* * *$ & * & NS \\
\hline & $\%$ LW & 1.25 & 1.36 & 1.32 & 1.33 & 1.26 & 0.04 & * & NS & NS \\
\hline
\end{tabular}

Note: $\mathrm{S}=$ species; $\mathrm{A}=$ age; $\mathrm{S} \times \mathrm{A}=$ Species $\times$ age interactions; ${ }^{*}=\mathrm{p}<0.05 ;{ }^{* *}=\mathrm{p}<0.01 ;{ }^{* * *}=\mathrm{p}<0.001 ; \mathrm{NS}=\mathrm{Non}$-significant; $\mathrm{SED}=$ standard error of difference. 
cantly $(p<0.001)$ between the species. The yield of heart percentage in proportion to body weight was found significantly higher $(\mathrm{p}<0.001)$ in buffalo $(0.40 \% \mathrm{LW})$ than in cattle $(0.30 \% \mathrm{LW})$.

The total GI tract (with content) was found significantly higher $(\mathrm{p}<0.001)$ in buffalo $(61.26 \mathrm{~kg})$ than in cattle $(53.32 \mathrm{~kg})$ and significantly higher $(\mathrm{p}<0.01)$ yield was observed in aged animal than a younger animal. Even though the empty stomach differed significantly between the species and among the ages, the ratio of the empty stomach with live weight was not significantly different. The empty rumen part also showed the same result, but there were significant effects of species $(p<0.05)$ on the percentage of the empty rumen with live weight.

\section{Physical and Chemical Properties of Meat}

The $\mathrm{pH}$ value of meat of warm carcass after 2 hours of slaughtering did not differ significantly between the species of cattle and buffalo and among the age groups (Table 4). In addition, there was no interaction of animal species and age on the $\mathrm{pH}$ of meat. Again, the $\mathrm{pH}$ value of meat of chilled carcass after 24 hours of slaughtering differed significantly among the age groups but not between the species of cattle and buffalo where the meat $\mathrm{pH}$ of the aged animal was found higher than those of medium or younger animal. There was no significant difference observed in case of drip loss of meat. However, in case of cooking loss, it was observed that more significant $(\mathrm{p}<0.05)$ cooking loss was observed in the meat of cattle $(20.3 \%)$ than in that of buffalo $(18.2 \%)$ and in the meat of aged animal cooking loss was higher $(p<0.05)$ than a younger animal. The marbling score of meat varied significantly between the species $(p<0.001)$ and among the age groups $(\mathrm{p}<0.05)$. Marbling score was measured higher in the meat of cattle (5.00) than buffalo (3.85) and among the age groups, it was found that the marbling score of meat increased linearly with the increased age of animals.
In contrast to the linear increased marbling score with age, the yield grade of meat of animals of different ages decreased linearly and significantly $(p<0.05)$. Most importantly, the finer meat was harvested from buffalo with yield grade 3, while the yield grade of beef was almost 3.5, which differed significantly between the species $(\mathrm{p}<0.05)$. The color of meat was significantly influenced by the species $(p<0.01)$ and age $(p<0.001)$. Buffalo meat (36.7) was found darker than cattle meat (40.1) and when the age of animals increased the darkness of meat increased linearly. At the same time, buffalo meat found more reddish in color than the cattle meat and when the age of animals increased, the yellowness of meat decreased over time linearly $(\mathrm{p}<0.05)$. In case of yellowness of meat, there was also found a significant interaction effect between species and age $(\mathrm{p}<0.05)$.

Dry matter, protein, and ash percentages of meat did not differ significantly between the species and among the age groups. The intramuscular fat was influenced very significantly $(p<0.001)$ by the interaction of species and age groups. Again, intramuscular fat of meat differed significantly $(\mathrm{p}<0.001)$ between the species and among the age groups $(p<0.01)$. A little amount of fat was found in meat of buffalo $(0.44 \%)$, which was even significantly lower than in that of cattle $(3.31 \%)$ and with a significant higher amount of fat was measured with the increased age in both the cattle and buffalo species.

\section{DISCUSSION}

The dressing percentage was influenced by the species $(p<0.001)$ and this finding of the current study is in line with the findings of Barton et al. (2006) that dressing percentage is significantly influenced $(p<0.001)$ by the species types. The findings of this study (Buffalo vs cattle $=52.1 \%$ vs $55.3 \%$ ) was almost similar with the findings of Mello et al. (2017) where they found a significantly lower $(\mathrm{p}<0.001)$ dressing percentage in buffalo than in cattle (Buffalo vs cattle $=52.1 \%$ vs $57.2 \%$ ). In this

Table 4. Physical and chemical properties of cattle and buffalo meats

\begin{tabular}{|c|c|c|c|c|c|c|c|c|c|}
\hline \multirow{2}{*}{ Variables } & \multicolumn{2}{|c|}{ Species } & \multicolumn{3}{|c|}{ Age (months) } & \multirow{2}{*}{ SED } & \multicolumn{3}{|c|}{ Sig. Level } \\
\hline & Cattle & Buffalo & 28 & 34 & 40 & & $S$ & A & SxA \\
\hline $\mathrm{pH}, 2$ hrs of postmortem (W) & 5.93 & 6.07 & 5.99 & 5.88 & 6.13 & 0.09 & NS & NS & NS \\
\hline $\mathrm{pH}, 24 \mathrm{hrs}$ of postmortem (C) & 5.64 & 5.84 & $5.63^{\mathrm{b}}$ & $5.63^{\mathrm{b}}$ & $5.96^{\mathrm{a}}$ & 0.08 & NS & * & NS \\
\hline Drip loss $\%$ & 11.3 & 11.3 & 11.0 & 11.6 & 11.2 & 0.55 & NS & NS & NS \\
\hline Cook loss $\%$ & 20.3 & 18.2 & $17.6^{\mathrm{b}}$ & $19.5^{\mathrm{bc}}$ & $20.7^{\mathrm{ac}}$ & 0.78 & * & * & NS \\
\hline Marbling score & 5.00 & 3.85 & $4.00^{\mathrm{b}}$ & $4.48^{\mathrm{bc}}$ & $4.80^{\mathrm{ac}}$ & 0.18 & $* * *$ & * & NS \\
\hline Yield grade & 3.470 & 3.052 & $3.112^{\mathrm{a}}$ & $3.269^{\mathrm{ab}}$ & $3.402^{\mathrm{b}}$ & 0.07 & * & * & NS \\
\hline$L^{*}$ (lightness) & 40.1 & 36.7 & $41.0^{\mathrm{a}}$ & $39.1^{\mathrm{a}}$ & $35.0^{\mathrm{b}}$ & 0.83 & $* *$ & $* * *$ & $* *$ \\
\hline$a^{*}$ (redness) & 15.8 & 17.4 & 16.8 & 17.0 & 16.0 & 0.50 & * & NS & NS \\
\hline$b^{*}$ (yellowness) & 9.9 & 10.8 & $11.7^{\mathrm{a}}$ & $10.2^{\mathrm{ac}}$ & $9.4^{\mathrm{bc}}$ & 0.44 & NS & * & $*$ \\
\hline Color intensity $\left(C^{*}\right)$ & 18.7 & 20.1 & 20.5 & 19.4 & 18.3 & 0.63 & NS & NS & NS \\
\hline $\mathrm{DM}$ & 27.0 & 26.1 & 26.4 & 27.0 & 26.3 & 0.63 & NS & NS & NS \\
\hline Protein & 20.8 & 20.2 & 20.6 & 20.7 & 20.2 & 0.24 & NS & NS & NS \\
\hline Fat (IM) & 3.31 & 0.44 & $1.54^{\mathrm{c}}$ & $1.90^{\mathrm{b}}$ & $2.19^{a}$ & 0.05 & $* * *$ & $* *$ & $* * *$ \\
\hline Ash\% & 4.01 & 4.29 & 4.31 & 4.09 & 4.05 & 0.18 & NS & NS & NS \\
\hline
\end{tabular}

Note: $\mathrm{S}=$ species; $\mathrm{A}=$ age; $\mathrm{S} \times \mathrm{A}=$ Species $\times$ age interactions; ${ }^{*}=\mathrm{p}<0.05 ;{ }^{* *}=\mathrm{p}<0.01 ;{ }^{* * *}=\mathrm{p}<0.001 ; \mathrm{NS}=$ Non-significant; $\mathrm{SED}=$ standard error of difference. 
experiment, we did not found any variation on the yield of longissimus muscle areas of native cattle and buffalo. However, Huerta-Leidenz et al. (2015) observed a variation in their experiment, where Brahman bulls outperformed on total valuable cuts $(p<0.05)$ over buffalo bull. The increased longissimus muscle area with the increase of age was very logical. Meat $\mathrm{pH}$ ranges from 5.4-5.6 ensures the higher quality level of meat (Węglarz, 2010) and this type of $\mathrm{pH}$ range proves that animals were not in the stressed condition at slaughtering (Tahuk et al., 2018). In this study, we found the ultimate meat pHs of buffalo and cattle were 5.34 and 5.26, respectively. Plessis \& Hoffman (2007) reported that the $\mathrm{pH}$ values of bulls and heifers at 24 hours of postmortem were not different significantly, but when the age was evaluated, they found a significant difference $(\mathrm{p}<0.05)$ in meat $\mathrm{pH}$. They reported $5.51 \mathrm{pH}_{24}$ for 18 months of age and $5.67 \mathrm{pH}_{24}$ for 30 months of age. In this experiment, the same trend of age effects on postmortem meat $\mathrm{pH}_{24}$ was observed.

In this experiment, a significant higher cooking loss was observed in cattle meat than in buffalo meat as well as with aged animal's meat than younger animal's meat. This result is similar to that reported by Schonfeldt \& Strydom (2011) that cooking loss of beef increased with age due to protein denaturation. The increased cooking loss may also be related to the changes in the physical and chemical properties of beef (Lin-qiang et al., 2011). Therefore, it could be concluded that the protein of buffalo meat denatured slowly compared to that of cattle meat, causing buffalo meat can hold more water than cattle meat at heating.

In this experiment, we found a higher marbling score for cattle than buffalo, and it has a strong logical correlation with cooking loss, lightness, and intramuscular fat. It was stated (Nam et al., 2009) that if intramuscular fat of longissimus dorsi muscle increased, then the drip loss and cooking losses would be decreased. The study of Lee \& Choi (2019) also agreed with this statement. The same things we found in our study except for drip loss. Again, Lee et al. (2018) stated that if the marbling score of any meat got high, then lightness of meat would be shown high and the same things were observed in our study. A marbling score also influences the measuring of yield grade of meat. The correlation between the marbling score and yield grade found in this study was also found in the study of Cox-O'Neill et al. (2017). The review of Gotoh et al. (2018) on Japanese grading system also similar to the result found in this experiment. The species character of buffalo is its meats are darker and reddish in color compared to beef or any other meats (Kandeepan \& Biswas, 2007) and in this experiment, we observed buffalo meat with the reddish appearance and the nature of more light absorbing compared to cattle meat. Kandeepan \& Biswas (2007) also reported that buffalo meat contained high protein but low fat and cholesterol compared to cattle meat. In this study, significantly lower intra-muscular fat was found in buffalo meat than in cattle meat which is in line with the above agreement.

In this experiment, there was also observed age effects on the presence of intramuscular fat in meat which was similar to the report of Lin-qiang et al. (2011), who found significant effects $(\mathrm{p}<0.01)$ of age on intra-muscular fat. Moreover, Lee \& Choi (2019) stated that with the increased intramuscular fat, the lightness of meat would increase $(p<0.05)$. Similar results were observed in our study. The dry matter, crude protein, and ash percentage results obtained from this experiment were not differed between species and among the age groups, which is also in line with the statement of Lin-qiang et al. (2011) and Serra et al. (2008). They did not find any significant variation in the proximate composition of longissimus dorsi muscle of different breeds or species. Carcass weight in all aspects was significantly higher in cattle than in buffalo in this experiment. However, getting more than $50 \%$ carcass weight from buffalo was remarkable. Lambertz et al. (2014) harvested up to $49.5 \%$ of carcass weight. As the carcass weight differed between the species, the forequarter and hindquarter also differed significantly between the species. Similarly, some parts of the primal cuts differed with species and age, but the major indicating parts were the chuck which differed significantly between the species and ages. This result was somewhat similar to the study of Singh et al. (2018) and Lambertz et al. (2014). At the same time, some noncarcass parts differed between the species and ages. This may happen because of species differences and body size for different ages.

Another thing is observed here, that is, in offal and most of the yield of non-carcass parts, buffalo had higher than cattle. This finding was somewhat similar to the findings of Priyanto et al. (2019). If we look forward to the age effect on yield or quality of meat of both species, it was observed that $\mathrm{pH}$, cooking loss, marbling score, and fat percentage increased linearly with the increase of ages, when dressing percentage remained non significant among different stages of age. Dressing percentages might be varied with age groups if yearling bulls were used. Ranjan (2004) stated that yearling buffalo bulls grew faster and reached a greater dressing percentage. It can be said that meat of the young animal is healthier than that of aged animals and rearing of the young animal is more economical. In this experiment, 28 to 40 months aged animals were used, where yield grade of meat was found better with buffalo and increased with the increase of age. If yearling and 40 months more aged animals were used, then it would be easier to find out the optimal slaughter age of both the species. However, buffalo meat performed better with most of the cases. Young animals of both the species also performed better than an aged animal.

\section{CONCLUSION}

In the end, it can be said that the only demerits of buffalo meat are it's more light absorption which makes it more reddish in color than cattle meat. Otherwise, on the basis of fat percentage, marbling score or yield grade of meat, buffalo meat is better than cattle meat, though its carcass yield was lower than cattle. The yield grade of meat of both the species increased with the increase of age. But, it is not sufficient to recommend the optimal 
slaughter age. More advanced research is required in this regard indeed.

\section{CONFLICT OF INTEREST}

We certify that there is no conflict of interest with any financial, personal, or other relationships with other people or organization related to the material discussed in the manuscript.

\section{REFERENCES}

AOAC. 2005. Official Methods of Analysis of AOAC International. 18th ed. Assoc. Off. Anal. Chem., Arlington.

Barton, L. D., V. Řehák, D. Teslík, R. Bureš, \& Zahrádková. 2006. Effect of breed on growth performance and carcass composition of Aberdeen Angus, Charolais, Hereford, and Simmental bulls. Czech J. Anim. Sci. 51: 47-53. https://doi. org/10.17221/3908-CJAS

Burson, D. E. 2005. Quality and Yield Grades for Beef Carcasses. North Central Regional Extension Publication \#357. University of Nebraska, Lincoln.

Cheng, W., J. Cheng, D. Sun, \& H. Pu. 2015. Marbling analysis for evaluating meat quality: Methods and techniques. Compr. Rev. Food Sci. Food Saf. 14: 523-535. https://doi. org/10.1111/1541-4337.12149

Cox-O'Neill, J. L., K. E. Hales, K. M. Ulmer, R. J. Rasby, J. Parsons, S. D. Shackelford, H. C. Freetly, \& M. E. Drewnoski. 2017. The effects of back grounding system on growing and finishing performance and carcass characteristics of beef steers. J. Anim. Sci. 95: 5309-5319. https://doi. org/10.2527/jas2017.1934

Fatema, M. K. 2014. Statistical Yearbook of Bangladesh. $34^{\text {th }}$ ed. Bangladesh Bureau of Statistics (BBS), Publication Section, Dhaka, Bangladesh.

Gotoh, T., T. Nishimura, K. Kuchida, \& H. Mannen. 2018. The Japanese wagyu beef industry: current situation and future prospects - A review. Asian Aust. J. Anim. Sci. 31: 933950. https://doi.org/10.5713/ajas.18.0333

Hale, D. S., K. Goodson, \& J. W. Savell. 2013. USDA Beef Quality and Yield Grade. Texas A \& M AgriLife Extension Service. College Station, TX 77843-2471.

Hamid, M. A., S. Ahmed, M. A. Rahman, \& K. M. Hossain. 2016. Status of buffalo production in Bangladesh compared to SAARC countries. Asian J. Anim. Sci. 10: 313-329. https://doi.org/10.3923/ajas.2016.313.329

Huerta-Leidenz, N., A. Rodas-González, A. Vidal, J. LopezNuñez, \& O. Colina. 2015. Carcass cut-out value and eating quality of longissimus muscle from serially harvested savannah-raised Brahman-influenced cattle and water buffaloes in Venezuela. Anim. Prod. Sci. 56: 2093-2104. https:// doi.org/10.1071/AN14987

Huque, Q. M. E. \& A. Borghese. 2013. Status and perspectives of buffalo in Bangladesh. Buffalo Bull. 32: 1179-1183.

Irurueta, M., A. Cadoppi, L. Langman, G. Grigioni, \& F. Carduza. 2008. Effect of aging on the characteristics of meat from water buffalo grown in the Delta del Paraná region of Argentina. Meat Sci. 79: 529-533. https://doi. org/10.1016/j.meatsci.2007.12.010

Kandeepan, G. \& S. Biswas. 2007. Effect of low temperature preservation on quality and shelf life of buffalo meat. Am. J. Food Technol. 2: 126-135. https://doi.org/10.3923/ ajft.2007.126.135

Kandeepan, G., S. Biswas, \& R. S. Rajkumar. 2009a. Buffalo as a potential food animal. Int. J. Livest. Prod. 1: 1-5.

Kandeepan, G., A. S. R. Anjaneyulu, N. Kondaiah, S. K. Mendiratta, \& V. Lakshmanan. 2009b. Effect of age and gender on the processing characteristics of buffalo meat. Meat Sci. 83: 10-14. https://doi.org/10.1016/j. meatsci.2009.03.003

Lambertz, C., P. Panprasert, W. Holtz, E. Moors, S. Jaturasitha, M. Wicke, \& M. Gauly. 2014. Carcass characteristics and meat quality of swamp buffaloes (Bubalus bubalis) fattened at different feeding intensities. Asian Aust. J. Anim. Sci. 27: 551-560. https://doi.org/10.5713/ajas.2013.13555

Lee, B. \& Y. M. Choi. 2019. Correlation of marbling characteristics with meat quality and histochemical characteristics in longissimus thoracis muscle from Hanwoo steers. Food Sci. Anim. Resour. 39: 151-161. https://doi.org/10.5851/ kosfa.2019.e12

Lee, Y., B. Lee, H. K. Kim, Y. K. Yun, S. J. Kang, K. T. Kim, B. D. Kim, E. J. Kim, \& Y. M. Choi. 2018. Sensory quality characteristics with different beef quality grades and surface texture features assessed by dented area and firmness, and the relation to muscle fiber and bundle characteristics. Meat Sci. 145: 195-201. https://doi.org/10.1016/j. meatsci.2018.06.034

Lin-qiang. L. I., T. I. A. N. Wan-qiang, \& Z. A. N. Lin-sen. 2011. Effects of age on quality of beef from Qinchuan cattle carcass. Agric. Sci. China. 10: 1765-1771. https://doi. org/10.1016/S1671-2927(11)60176-4

Mello, J. L. M., A. B. B. Rodrigues, A. Giampietro-Ganeco, F. B. Ferrari, R. A. Souza, P. A. Souza, H. Borba. 2017. Characteristics of carcasses and meat from feedlot-finished buffalo and Bos indicus (Nellore) bulls. Anim. Prod. Sci. 58: 1366-1374. https://doi.org/10.1071/AN16556

Mir, P. S., Z. Mir, P. S. Kuber, C. T. Gaskins, E. L. Martin, M. V. Dodson, J. A. Calles, K. A. Johnson, J. R. Bubsoom, A. J. Wood, G. J. Pittenger, \& J. J. Reeves. 2002. Growth, carcass characteristics, muscle conjugated linoleic acid (CLA) content and response to intravenous glucose challenge in high percentage Wagyu, Wagyu $\times$ Limousin and Limousin steers fed sunflower oil containing diets. J. Anim. Sci. 80: 2996-3004. https://doi.org/10.2527/2002.80112996x

Nam, Y. J., Y. M. Choi, S. H. Lee, J. H. Choe, D. W. Jeong, Y. Y. Kim, \& B. C. Kim. 2009. Sensory evaluations of porcine longissimus dorsi muscle: Relationships with postmortem meat quality traits and muscle fiber characteristics. Meat Sci. 83: 731-736. https://doi.org/10.1016/j. meatsci.2009.08.015

Naveena, B. M., M. Kiran, K. S. Reddy, C. Ramakrishna, S. Vaithiyanathan, \& S. K. Devatkal. 2011. Effect of ammonium hydroxide on ultrastructure and tenderness of buffalo meat. Meat Sci. 88: 727-732. https://doi.org/10.1016/j. meatsci.2011.03.005

Plessis, I. \& L. C. Hoffman. 2007. Effect of slaughter age and breed on the carcass traits and meat quality of beef steers finished on natural pastures in the arid subtropics of South Africa. S. Afr. J. Anim. Sci. 37: 143-153. https://doi. org/10.4314/sajas.v37i3.4084

Priyanto, R., H. Nuraini, Muladno, M. Ismail, \& H. Wijayanto. 2019. Slaughter, carcass and non-carcass characteristics of local cattle and buffalo in Indonesia. Pak. J. Nutr. 18: 117124. https://doi.org/10.3923/pjn.2019.117.124

Rahman, M. N. 2012. Statistical Yearbook of Bangladesh, $32^{\text {nd }}$ ed. Reproduction Documentation and Publication, Bangladesh Bureau of Statistics (BBS), Dhaka, Bangladesh.

Ranjan, S. K. 2004. Commercial production of buffalo meat with social agenda. Proceedings of $7^{\text {th }}$ World Buffalo Congress, Makat, Phillipines. pp. 1-7.

Ranjhan, S. K. 2014. Indian buffalo meat industry vis-à-vis international trade. In the $6^{\text {th }}$ Conference of Indian Meat Science Association and National Symposium on Sustainable Meat Production for Nutritional Security and Consumer Wellbeing: Challenges and Strategies, DUVASU, Mathura, India. 
Schonfeldt, H. C. \& P. E. Strydom. 2011. Effect of age and cut on cooking loss, juiciness and flavour of South African beef. Meat Sci. 87: 180-190. https://doi.org/10.1016/j. meatsci.2010.10.007

Serra, X., L. Guerrero, M. D. Gua'rdia, M. Gil, C. Sañudo, B. Panea, M. M. Campo, J. L. Olleta, M. D. Garcı'a-Cacha'n, J. Piedrafita, \& M. A. Oliver. 2008. Eating quality of young bulls from three Spanish beef breed-production systems and its relationships with chemical and instrumental meat quality. Meat Sci. 79: 98-104. https://doi.org/10.1016/j. meatsci.2007.08.005

Singh, P. K., S. S. Ahlawat, D. P. Sharma, \& A. Pathera. 2018. Carcass characteristics of male buffalo calf and meat quality of its veal. Buffalo Bull. 37: 129-144.
Steel, R. G. \& J. E. Torrie. 1980. Principles and Procedures of Statistics. McGraw Hill Book, New York.

Tahuk, P. K., S. P. S. Budhi, Panjono, \& E. Baliarti. 2018. Carcass and meat characteristics of male Bali cattle in Indonesian smallholder farms fed ration with different protein levels. Trop. Anim. Sci. J. 41: 215-223. https://doi. org/10.5398/tasj.2018.41.3.215

Van Soest, P. J., J. B. Roberson, \& B. A. Lewis. 1991. Methods for dietary fiber, neutral detergent fiber and nonstarch polysaccharides in relation to animal nutrition. J. Dairy Sci. 74: 3583-3597. https://doi.org/10.3168/jds. S0022-0302(91)78551-2

Węglarz, A. 2010. Meat quality defined based on $\mathrm{pH}$ and color depending on cattle category and slaughter season. Czech J. Anim. Sci. 55: 548-556. https://doi.org/10.17221/2520-CJAS 